\title{
AUDIT IN THE DOMINANT ENTERPRISE ON THE MARKET - THE EXAMPLE OF POLISH POST
}

\author{
Artur Piaszczyk
}

\section{Key words:}

audit, dominant enterprise, postal services, monopoly

\begin{abstract}
The purpose of this paper is to present and analyze the role and responsibilities of the audit in the dominant enterprise in the market of postal services. To achieve the target, it discussed two major issues: EU regulations on competition policy and the audit in the Polish Post Office - the dominant enterprise in the market for postal services in Poland.
\end{abstract}

\section{Introduction}

The dominance of the market is not a good thing. This applies to the dominance of both: producer and consumer dominance - which is much less common. The dominance of OPEC ${ }^{1}$ on the oil market led in 1973 - 1974 price shock and threefold increase in real prices of oil ${ }^{2}$. Similar cases, although on a much smaller scale, are seen every day in many markets around the world.

In order to limit adverse events to the economy of market dominance, the European Union has taken decisive action, mainly for the rules of law. EU also encouraged businesses to independently and voluntarily resigned from the use of its dominant market position. One of the possible actions, the self-limitation of entrepreneurs, is the focus of the audit risk analysis for adverse events resulting from use of a dominant position.

This paper aims to explain and analyze the actions taken to reduce the dominant position of companies in the market, both in terms of EU regulations, and voluntary action by businesses in this area.

\section{EU regulations on competition in the market}

One of the objectives of the European Union's competition policy is to ensure that dominant companies are not using their market power to restrict competition. This policy focuses on consumer choice and to maintain a level playing field for companies operating in the common market.

Article 82 of the Treaty of the European Community and Regulation (EC) No 1 / 2003 imposes a ban on abuse of dominant position by companies on the market, insofar as it may affect trade between Member States. Article 82 of the EC Treaty itself does not prohibit a dominant position, but only its abuse in the market in so far as it may affect trade between Member States. The aim is to prevent abuse of dominant position by dominant companies in their sector of the economy and prevent distortions of competition in intra-Community trade.

\footnotetext{
${ }^{1}$ OPEC - Organization of the Petroleum Exporting Countries.

${ }^{2}$ See: D. Begg, S. Fischer, R. Dornbush, Ekonomia. Mikroekonomia, wydanie III zmienione (Economics. Sixth Edition), Polskie Wydawnictwo Ekonomiczne, Warszawa 2003, p. 31.
} 
EU regulations do not define the concept of dominance, but only give examples of actions are an abuse of dominant position. These are for example:

- imposing prices or other trading conditions;

- limiting production, markets or technical development to the detriment of consumers;

- imposing supplementary obligations which have no connection with the contract;

- the granting of discounts so-called loyal customers that discourage consumers from using the services of the other companies.

In order to curb described practices, there has been a reform in the EU, involving a change in Community law. The reform took place enforcement procedures under Council Regulation (EC) No 1 / 2003 of 16 December 2002, which came into force on 1 May 2004. The most important regulations are as follows:

- enable more effective application of Community competition law based on the decentralized implementation system to be used both by the Commission competition authorities and courts of the Member States. The Regulation has introduced a system of legal exemptions that make an agreement which does not violate the competition rules, are automatically considered to be permitted, and also replaced the previously mandatory system based on the principle of prohibition.

- the European Commission retains significant powers in the field of decision with respect to the initiation of proceedings in individual cases to the decision to violate the law, issuing an order to cease illegal practices or inability to use, and acquisition matters of national authorities;

- it was increased powers for the Commission in carrying out spot checks;

- legislation was adopted on the systematic cooperation between national authorities and the European Commission.

In parallel with legal action, the European Union has started to encourage entrepreneurs to voluntary action on the resignation of the privileges of a dominant market position. One such action is an audit approach to in-depth analysis of the risk $^{3}$ posed by restricting competition, particularly in the services sector.

The importance of audit increases because especially in large companies, the board has a limited ability to exercise direct control over the correctness of ordering and service, and often supervisory boards, required to supervise the activities of the Management Board, also it wants to have the opinion of the independent auditors. In addition, services are vanishing, which severely hampers their direct control by management ${ }^{4}$.

The specificity of the dominant audit firms is, in my opinion, primarily to protect the company from the negative effects of abuse of dominant position. Mode of action of the auditor, to ensure such protection, should result from risk analysis.

A good example of the lack of proper risk analysis in this regard is the case of Microsoft. In 2004 the European Commission found Microsoft guilty of a company abuses almost monopolistic position in the market for operating systems for personal computers. The

\footnotetext{
3 The Committee of Sponsoring Organizations of the Treadway Commission (COSO), Enterprise Risk Management Framework, Orlando Florida, 2004, p. 1.

${ }^{4}$ The Committee of Sponsoring Organizations of the Treadway Commission (COSO), Internal Control Integrated Framework, Orlando Florida, 1992; Polish edition: Kontrola wewnętrzna, Fundacja Rozwoju Rachunkowości, Warszawa 1999, s. 7.; A. Piaszczyk, Audyt wewnętrzny, Stowarzyszenie Księgowych w Polsce, Zarząd Główny, Centralny Ośrodek Szkolenia Zawodowego, Warszawa 2005, s. 11-12.
} 
Commission found that Microsoft acted illegally by preventing data exchange with competing operating systems and combining the products and thereby limiting consumer choice. The Commission decision was upheld in 2007 by the EU Court of First Instance and the Court of Justice in Luxembourg. At Microsoft imposed a fine of EUR 899 million.

At this point you can, in theory, present scheme of conduct audit of the dominant undertaking. It is a model diagram which can be used by auditors employed in such dominant enterprises.

The main advantage of this model is the focus of audit risk analysis. Risk analysis is, in this sense, the current at each stage of the audit and the audit supports the activities of an entity through the assessment of business operations before and after their implementation.

\section{Diagram 1 Schematic conduct an audit of the dominant enterprise}

Planning for business operations

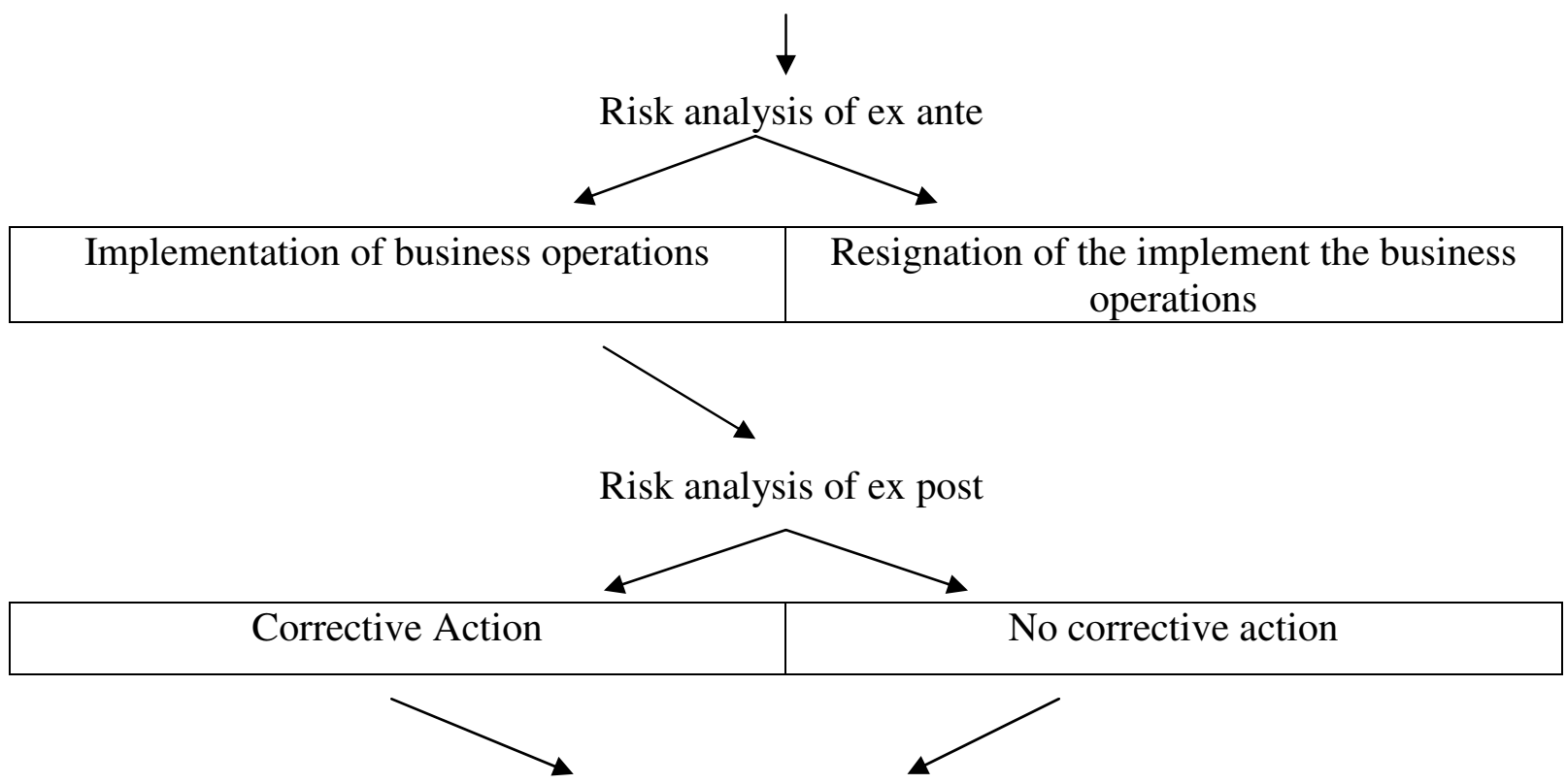

Monitoring and evaluation of the effects of the business operation

Source: own.

\section{Audit in the Polish Post Office - research results ${ }^{5}$}

In 2008, there has been a commercialization of state-owned public utility "Polish Post". From that date it is called "Polish Post Joint-Stock Company (JSC)", and its sole owner is the State Treasury.

The company is undoubtedly the dominant company in the market for postal services, in some areas almost a monopoly. It has the exclusive right to use the word "post" in the name of the company, in various cases, and a registered trade mark. It has a unique status in Poland, the

\footnotetext{
5 The concept of research, sampling methodology and data presentation are based on the: C. FrankfortNachmias, D. Nachmias, Metody badawcze w naukach spotecznych (Research Methods in the Social Sciences), wyd. I, Zysk i S-ka, Poznań 2001; D. Begg, S. Fischer, R. Dornbush, Ekonomia. Mikroekonomia, op. cit., pp. 5069.
} 
public operator, who is entitled to a grant from the state budget if the company takes down the loss.

Polish Post is statutorily obliged to provide universal postal services. This means that it is obliged to provide services consisting of the reception and delivery of:

- letters up to $2 \mathrm{~kg}$,

- packages up to $10 \mathrm{~kg}$ (package awarded abroad can have a weight of $20 \mathrm{~kg}$ ),

- consignment for the blind,

- postal orders.

The Post can not refuse to execute anyone universal postal service, provided that the person applies to the records of the Rules providing these services.

Beside the Polish Post Office in Poland there are many other postal operators, but they do not have the status of the public operator. What's more, only the Polish Post shall have the exclusive right to provide services in the course of delivery by a weight not exceeding 50 grams; in this respect, the Polish Post is a monopolist.

According to the information contained in the report of the Office of Electronic Communications ${ }^{6}$ on the state of the postal services market in Poland, apart from the Polish Post, the register of postal operators is listed 209 entities. However, not all operators who have obtained an entry, in fact they operate.

${ }^{7}$ In 2010, the Polish Post has realized in the domestic and foreign trade nearly 2.3 bln postal services (universal services, contractual, express), which resulted in over 5 billion PLN revenue (approximately 1.7 billion US dollars). In this number of services were more than 1.9 billion universal services, which generated nearly 4.6 billion PLN revenue. Non-public operators realized total (domestic and foreign), almost 3.2 billion postal services (items of correspondence, direct mail, parcels, unaddressed printed matter), which translates into nearly 1.2 billion PLN revenue. The largest share of the domestic market in terms of quantity have unaddressed printed matter (95.6 percent), which did not play such a significant role in the revenue of operators (14 percent). The main source of revenue for private operators are packages - in domestic trade, they generate approximately 58.4 percent revenues, and foreign trade of about 71.6 percent. $^{8}$

Polish Post is by far the dominant entity in the area of items of correspondence and direct mail (its shares are respectively $92.2 \%$ and $90.5 \%$ of the market). In the parcel segment shares were divided evenly fairly. In the area of unaddressed printed matter definite advantage in terms of volume (90.4 percent) and revenue (83.6 percent) non-public operators have. Activity in the area of unaddressed printed matter may be conducted without an entry in the register of postal operators, so the Office of Electronic Communications does not have complete data in this area.

\footnotetext{
${ }^{6}$ Urząd Komunikacji Elektronicznej, Raport o stanie ustug pocztowych w Polsce w 2010, www.uke.gov.pl (The Office of Electronic Communications, Report on the state of postal services in Poland in 2010, www.uke.gov.pl.)

${ }^{7}$ The information in this paragraph and the next two by: Urząd Komunikacji Elektronicznej, Raport o stanie ustug pocztowych $w$ Polsce $w 2010$, op. cit.

${ }^{8}$ Ibid.
} 
There is still a large area reserved, that is part of the market, which is reserved for the public operator. The reserved area is about 3 / 4 of the total market for postal services (excluding unaddressed printed matter) and generates about half of revenue. The main beneficiary of the benefits of activity in this area of the market remains the Polish Post.

An important task for the authorities of the state is developing a new Postal Law, because of the need to implement the provisions of the Third Postal Directive ${ }^{9}$, and also because of the need to organize the legal environment in which postal operators operate. In Poland, the implementation of the provisions of the Third Postal Directive is expected by the end of 2012 and it will mean the abolition of monopoly of the Polish Post Office in areas where there is a monopoly.

In order to verify the thesis that the audit system in the dominant companies is different from the audit system in other enterprises, I conducted the study ${ }^{10}$.

There were selected for the tests of public interest entities, which are public companies listed on the Warsaw Stock Exchange. With a population of public interest entities were selected to test all domestic public companies. At the time of the study there were in Poland 354 domestic public companies. The study was conducted in the form of a questionnaire. Surveys were sent to all domestic public companies - 354 units - by e-mail. 108 returns were received, representing $30.51 \%$ of the population. The resulting number of responses can be regarded as representative, taking into account the basic criterion for selection, the inclusion of all units in the population of public interest entities.

Studies among internal auditors in the Polish Post Office were also in the form of a questionnaire. In the study took part 21 internal auditors of the Polish Post working in various locations throughout the country.

One survey question was: Will the introduction of public scrutiny of the audit quality is needed?

The answer to this question is presented in Table 1 (all results in all tables are presented in percentage terms.)

\section{Table 1 The need for public scrutiny of the audit quality}

\begin{tabular}{|l|c|c|}
\hline \multicolumn{1}{|c|}{ Specification } & Yes & No \\
\hline Managers & 73 & 27 \\
\hline Internal auditors & 95 & 5 \\
\hline
\end{tabular}

Source: own study based on surveys.

The next question addressed to those who responded affirmatively to the question about the need for supervision, was: Why do you think, the public scrutiny of the audit quality is needed? You can take more than one answer:

a) the credibility of financial statements will increase

b) the confidence in the quality of research will increase

c) the risk of accounting fraud and abuse will reduce

\footnotetext{
${ }^{9}$ Dyrektywa Parlamentu Europejskiego i Rady 2008/6/WE z dnia 20 lutego 2008 (Directive of the European Parliament and Council 2008/6/EC of 20 February 2008).

${ }^{10}$ The quoted studies are part of a larger research which results will be presented in a separate paper.
} 
d) other (please specify)

Answers are presented in Table 2.

Table 2 The reasons for the need for public scrutiny of the audit quality

\begin{tabular}{|c|c|c|c|c|}
\hline Specification & $\begin{array}{c}\text { The } \\
\text { credibility of } \\
\text { reports will } \\
\text { increase }\end{array}$ & $\begin{array}{c}\text { The confidence } \\
\text { in the quality of } \\
\text { research will } \\
\text { increase }\end{array}$ & $\begin{array}{c}\text { The risk of } \\
\text { accounting } \\
\text { fraud and abuse } \\
\text { will reduce }\end{array}$ & Other \\
\hline Managers & 88 & 50 & 63 & 0 \\
\hline $\begin{array}{l}\text { Internal } \\
\text { auditors }\end{array}$ & 62 & 29 & 90 & 0 \\
\hline
\end{tabular}

Studies show that a clear majority of respondents in each group advocates the need for a public scrutiny of the audit quality. The main reason for such needs, the vast majority of managers mentioned the increase in the reliability of financial statements, the majority of internal auditors indicated to reduce the risk of accounting fraud and abuse.

It should be noted that the study clearly demonstrate the specificity audit of the Polish Post, which is the dominant company of the market, and consisting in the fact that in such an undertaking audit focuses primarily on risk analysis. It also draws attention to the fact that 90\% of the Polish Post auditors found that the introduction of public scrutiny of the audit quality will reduce the risk of fraud. It is a further confirmation of the thesis that in the dominant companies the audit focused primarily on risk analysis.

The next question was: Is your company using EU funds? Granted affirmative answers: 73\% of managers and $100 \%$ of the internal auditors of the Polish Post.

The second question on the issues of EU funds was: Is the control of the EU funds should be:

a) exacerbated

b) mitigated

c) unchanged?

Answers are presented in Table 3.

Table 3 Control laws regulate the use of EU funds

\begin{tabular}{|l|c|c|c|}
\hline \multicolumn{1}{|c|}{ Specification } & Exacerbate & Mitigate & No change \\
\hline Managers & 9 & 46 & 45 \\
\hline Internal auditors & 5 & 14 & 81 \\
\hline
\end{tabular}

Source: own study based on surveys.

The results are divergent in both groups. The auditors strongly prevailing view that regulations should be left unchanged, and almost half of the managers believe that it needs to ease the control of EU funds. These results show that auditors are unlikely to recognize the issue being examined as a risky area. The results also show that the auditors of the Polish Post are not afraid of the control of the use of EU funds and therefore can not postulate the relaxation of this control. 
The following questions relate to financial reporting quality and auditing quality. The first two questions were: Do you have confidence in the performance of external auditors? And Do you have reservations about the performance of external auditors?

The answers to these questions are presented in Tables 4 and 5.

Table 4 Confidence in the performance of external auditors

\begin{tabular}{|l|c|c|}
\hline \multicolumn{1}{|c|}{ Specification } & Yes & No \\
\hline Managers & 91 & 9 \\
\hline Internal auditors & 43 & 57 \\
\hline
\end{tabular}

Source: own study based on surveys.

Table 5 Objections to the results of the work of external auditors

\begin{tabular}{|l|c|c|}
\hline \multicolumn{1}{|c|}{ Specification } & Yes & No \\
\hline Managers & 36 & 64 \\
\hline Internal auditors & 52 & 48 \\
\hline
\end{tabular}

Source: own study based on surveys.

The results clearly show that managers in majority have confidence in the performance of external auditors and they have no objection to them; one third of respondents from this group has reservations.

Internal auditors of the Polish Post do not trust the results of the work of external auditors and have objections to their work of auditors. More than half of the respondents in this group does not trust the results of the work of external auditors and more than half have a reservation. This is another issue for which the results of the Polish Post Office are clearly different from the results of research in public companies.

It should be noted that one element of the new audit system is the institution of the company auditor (external auditor), based on the trust of customers and other users opinion on the financial statements. Lack of confidence of internal auditors in the Polish Post Office for performance external auditors clearly distinguishes the Polish Post Office from the rest of the surveyed enterprises.

Another question concerned the audit and control system was: Does your company have a system of audit and control? Affirmative answer to this question has granted $91 \%$ of managers and $81 \%$ of internal auditors.

The next question asked respondents to assess audit and control system in their company.

Answers are contained in Table 6. 
Table 6 Assessment audit and control system

\begin{tabular}{|l|c|c|c|}
\hline \multicolumn{1}{|c|}{ Specification } & $\begin{array}{c}\text { Entirely } \\
\text { suitable }\end{array}$ & $\begin{array}{c}\text { It requires minor } \\
\text { improvements }\end{array}$ & $\begin{array}{c}\text { It requires } \\
\text { major changes }\end{array}$ \\
\hline Managers & 10 & 90 & 0 \\
\hline Internal auditors & 52 & 43 & 5 \\
\hline
\end{tabular}

Source: own study based on surveys.

The results show that the vast majority of respondents managers believe audit and control systems in their companies for demanding small improvements or completely right. No manager assessed the audit and control system in his company as requiring major changes. In the group of internal auditors is generally acknowledged that the audit and control system is perfectly adequate - believes that $52 \%$ of respondents.

From the presented results it can be concluded that the internal auditors of the Polish Post are most satisfied with the audit and control system in their company, which indicates the specificity of this company as a market-dominant postal services. If the company does not threaten serious competition, there is no need to make changes.

\section{Conclusion}

The study allows to formulate the following conclusions:

1. The results confirm the specificity of the audit system in the Polish Post, consisting in the orientation of the system for risk analysis. Thus, the obtained positive verification of the thesis that the audit system in enterprises dominating in the market is different from the other companies.

2. The internal auditors of the Polish Post did not postulate relaxing control on the use of European Union funds, which may suggest that they are not afraid of such control, which significantly differ from the rest of the surveyed enterprises.

3. The auditors of the Polish Post do not trust the results of the work of external auditors and have objections to their work. This point of view presents more than half of those surveyed internal auditors of the Polish Post. This is another issue for which the results of the Polish Post clearly differ from the results of research in public companies, where $91 \%$ of respondents trust the results of the work of external auditors and $64 \%$ have no objections to their work.

4. As many as $90 \%$ internal auditors of the Polish Post found that the introduction of public oversight of the audit quality of financial statements will reduce the risk of fraud. It is a further confirmation of the thesis that in the dominant companies the audit focuses primarily on risk analysis.

5. In the group of internal auditors of the Polish Post prevailing view that the system of audit and control in their company is perfectly adequate - believes that $52 \%$ of respondents. Clearly indicates that the specificity of this company as dominant in the market for postal services, which need not make any changes, because it does not seriously threaten competition. 
Presented and tested system of auditing the company, both in the Polish Post, as well as public companies, is coherent and consistent with generally accepted international standards in this area. ${ }^{11}$

\section{Literature:}

[1] BEGG, D., FISCHER, S., DORNBUSH, R. Ekonomia. Mikroekonomia. wydanie III zmienione (Economics. Sixth Edition), Polskie Wydawnictwo Ekonomiczne, Warszawa 2003.

[2] COSO (The Committee of Sponsoring Organizations of the Treadway Commission), Internal Control - Integrated Framework, Orlando Florida, 1992; the Polish edition: Kontrola wewnętrzna, Fundacja Rozwoju Rachunkowości, Warszawa 1999.

[3] COSO, Enterprise Risk Management Framework, Orlando Florida, 2004.

[4] FRANKFORT-NACHMIAS, C., NACHMIAS, D. Metody badawcze $w$ naukach spotecznych (Research Methods in the Social Sciences). wyd. I, Zysk i S-ka, Poznań 2001.

[5] PIASZCZYK, A. Audyt wewnętrzny. Stowarzyszenie Księgowych w Polsce, Zarząd Główny, Centralny Ośrodek Szkolenia Zawodowego, Warszawa 2005.

[6] Urząd Komunikacji Elektronicznej, Raport o stanie ustug pocztowych w Polsce w 2010, www.uke.gov.pl. (The Office of Electronic Communications, Report on the state of postal services in Poland in 2010, www.uke.gov.pl.)

[7] Dyrektywa Parlamentu Europejskiego i Rady 2008/6/WE z dnia 20 lutego 2008 (Directive of the European Parliament and Council 2008/6/EC of 20 February 2008).

JEL M42, L43

\section{Artur Piaszczyk, Ph.D.}

Internal auditor at the Jagiellonian University in Krakow

Czapski street 4, 31-110 Krakow, Poland

artur.piaszczyk@uj.edu.pl

Lecturer at the Chair of Banking and Finance

School of Finance and Law in Bielsko-Biala

Tanski street 5, 43-382 Bielsko-Biala, Poland

piaartur@interia.pl

\footnotetext{
${ }^{11}$ See: The Committee of Sponsoring Organizations of the Treadway Commission (COSO), Internal Control Integrated Framework, op. cit. and COSO, Enterprise Risk Management Framework, op. cit.
} 